\title{
PENGEMBANGAN MODUL PEMBELAJARAN MATEMATIKA BERBASIS SAINTIFIK
}

\author{
Yulistiana $^{1}$, Achi Rinaldi ${ }^{2}$, Abi Fadila ${ }^{3}$ \\ ${ }^{1,2,3}$ UIN Raden Intan J1. Letnan Kolonel H Jl. Endro Suratmin, Sukarame, Lampung \\ ${ }^{1}$ Yulistiana392@gmail.com
}

\begin{abstract}
Abstrak
Penelitian ini bertujuan untuk: 1) Mengembangkan dan Mengetahui kualitas modul pembelajaran matematika pada materi lingkaran berbasis saintifik ditinjau dari kevalidan dan keefektifan. Jenis penelitian ini adalah penelitian pengembangan prduk, berupa modul yang dikembangkan dengan berbasis saintifik. Dalam pengembangan modul ini peneliti mengacu pada model pengembangan 4D yang terdiri dari 4 tahap (Define, Design, Development, dan Disseminate) yaitu: (1) Define yang meliputi observasi langsung pada siswa di lapangan, (2) Design yang meliputi penyusunan modul dari aspek isi, bahasa, saintifik yang disesuaikan dengan kebutuhan siswa, (3) Development yang meliputi tahap pembaharuan produk awal yang telah diselesaikan dan kemudian diperbaiki, (4) Disseminate ialah tahap penggunaan prduk yang telah diperbaiki kemudian disebarluaskan ke lapangan., berdasarkan hasil angket respon siswa dan hasil evaluasi oleh ahli materi dan ahli media, efektif dengan ketuntasan hasil belajar yang sangat baik. Sehingga dapat disimpulkan bahwa modul pembelajaran matematika berbasis saintifik ini berhasil dikembangkan manjadi bahan ajar yang lebih baik karena telah disusun sesuai dengan kebutuhan siswa dan mampu memberikan kebermanfaatan bagi pembelajaran.
\end{abstract}

Kata kunci : Modul; Pendekatan Saintifik; Matematika

\begin{abstract}
This research aims to: 1) Develop and know the quality of mathematical learning modules in scientific-based circle materials reviewed from validity and effectiveness. This type of research was prduk development research, in the form of modules developed scientifically based. In the development of this module researchers refer to a 4D development model consisting of 4 stages (Define, Design, Development, and Disseminate) namely: (1) Define which includes direct observation on students in the field, (2) Design which includes the preparation of modules of content, language, scientific aspects tailored to the needs of students, (3) Development which includes the initial product renewal stage that has been completed and then repaired, (4) Disseminate was the level of use of prduk that has been improved then disseminated to the field., based on the results of student response questionnaires and evaluation results by material experts and media experts, effective with the completed results of excellent learning. So it can be concluded that this scientific-based mathematical learning module was successfully developed as a better teaching material because it has been structured according to the needs of students and able to provide benefits for learning.
\end{abstract}

Keywords : Module; Scientific Approach; Math 


\section{Pendahuluan}

Pendidikan adalah senjata paling mematikan, dengan pendidikan yang tinggi dan luasnya pengetahuan seseorang dapat menguasai dunia (Kurniawan, 2016; Ngafifi, 2014). Dengan demikian dijelaskan bahwa pendidikan begitu penting bagi seseorang apalagi dengan perkembangan zaman yang semakin canggih (Mawardi, 2016; Noor, 2019; Suharni, 2015), seseorang dapat dengan mudah memperoleh pendidikan dengan berbagai metode yang sesuai dengan kebutuhan masing-masing (Alifah dkk., 2019; Maesaroh, 2013). Perkembangan pendidikan menjadi suatu alat yang terus berubah dan berkembang secara signifikan (Nugroho dkk., 2019), sehingga dunia pendidikan mampu merubah pola pikir pendidik, anak didik, dan masyarakat awam, untuk dapat berpikir modern (Ibda \& Rahmadi, 2018; Pramesty, 2013; Supriadi, 2017). Seiring zaman dan diimbangi dengan berkembangnya kurikulum dalam pendidikan sebagai perangkat, rencanaan dan aturan tentang target, isi dan pembelajaran yang disertai tata cara penyelenggaraan pembelajaran (Sari, 2014).

Siswa lebih aktif dalam kegiatan pembelajaran sedangkan guru hanya sebagai fasilitator saja (Mastur, 2017). Terdapat banyak cara dalam kegiatan pembelajaran yang dapat digunakan seperti halnya menggunakan model pembelajaran tertentu, seperti pembelajaran yang dimana kegiatan belajar itu dihubungkan dengan lingkungan sekitar agar siswa juga lebih mudah untuk memahami materi yang diberikan oleh guru (Khasanah \& Fadila, 2018). Pendekatan saintifik yang dimana pendekatan saintifik ini menuntut siswanya aktif dalam pembelajaran mulai dari mengamati materi, bertanya tentang pelajaran yang telah diamati, mengumpulkan informasi sebanyak mungkin dari sumber baik itu buku, ataupun yang lainnya (Wibowo, 2015). Disini siswa juga akan melakukan diskusi, menalar akan materi pembelajaran dan juga akan dilihat bagaimana para siswa berkomunikasi dengan rekan sekelompoknya atau pun teman-teman yang lain (Wiyanto, 2003).

Siswa juga memerlukan bahan ajar sebagai sarana untuk menunjang kelancaran dalam kegiatan pembelajaran, baik itu sebuah buku atau media pembelajaran lainnya yang dapat membuat siswa lebih mudah mengikuti kegiatan pembelajaran dan lebih tertarik untuk belajar (Abdullah, 2017; Suda, 2016), sehingganya minat belajar siswa itu sendiri akan meningkat (Somayasa dkk., 2013). Supaya meningkatnya minat belajar siswa sehingga siswa bisa lebih tertarik akan pembelajaran matematika, lebih memperhatikan pembelajaran dan dengan seperti itu akan begitu berpengaruh dengan meningkatnya hasil belajar siswa(Siti Nurhasanah \& A.Sobandi, 2016). 
Modul juga merupakan bahan ajar yang telah memenuhi syarat kelayakan untuk digunakan sebagai salah satu penunjang dalam kegiatan belajar mengajar dan telah melewati beberapa tahap pengujian yang telah divalidasi oleh ahli materi, ahli media, uji terbatas, serta uji coba lapangan (Lukman \& Ishartiwi, 2014). Penelitian yang (Karlina, 2017) hasil penelitiannya berhasil dan produk layak untuk digunakan. Perbedaannya adalah bahan ajar yang dikembangkan untuk Program Studi Pendidikan Agama Islam. Persamaannya adalah mengembangkan modul berbasis saintifik dan penelitian (Setiyadi, 2017) Perbedaan dari penelitian ini adalah penelitian untuk meningkatkan hasil belajar siswa. Persamaannya adalah pengembangan modul berbasis Pendekatan Saintifik.

\section{Metode Penelitian}

Penelitian yang dilakukan merupakan jenis penelitian Research and Development (R\&D) dengan menggunakan model 4D yang dikemukakan oleh Thiagarajan, Semmel dan Semmel. Model ini terdiri atas 4 tahap pengembangan, yaitu define, design, develop, dan desseminate. Berikut merupakan uraian dari tahapan model 4D:

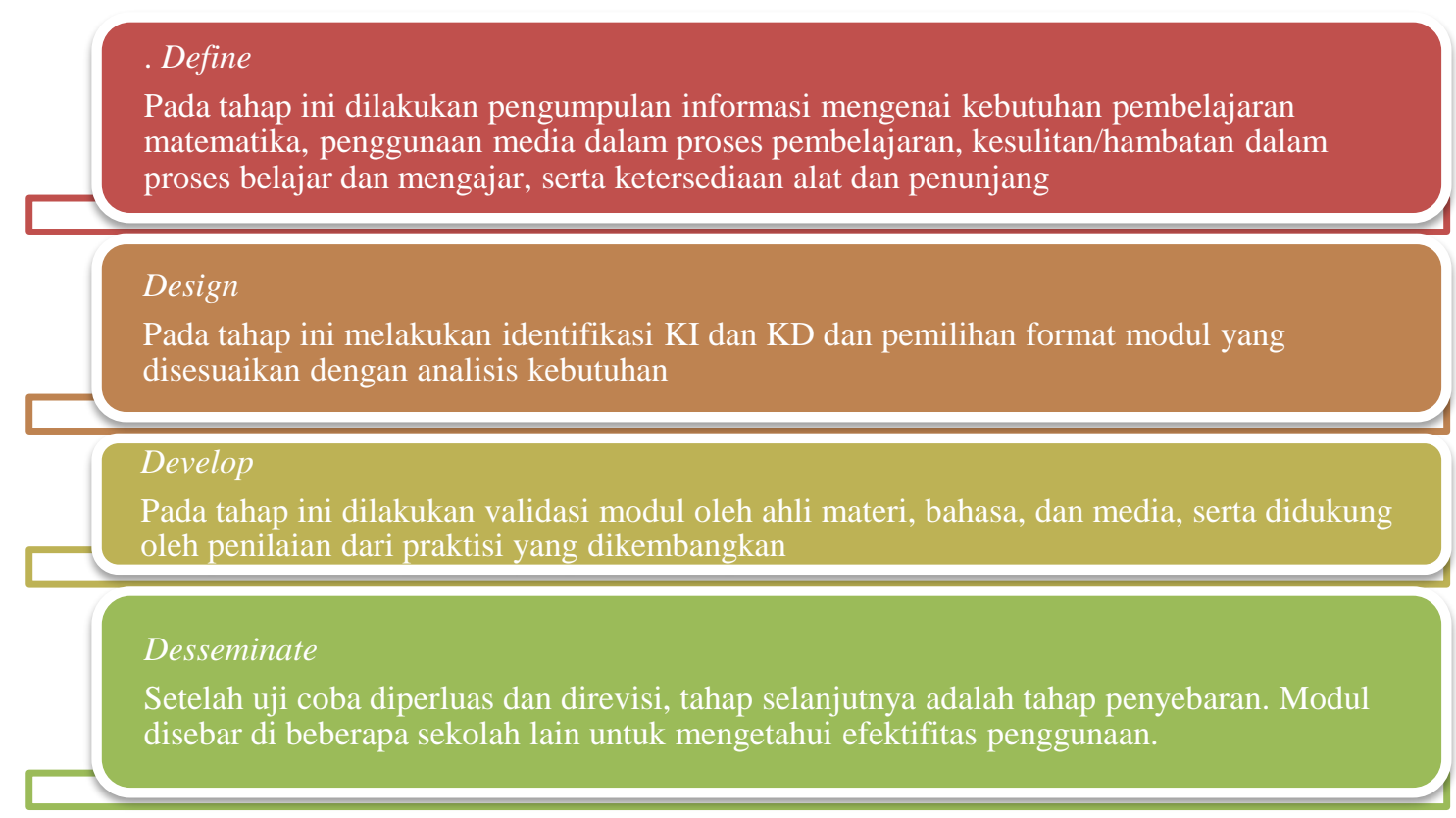

Populasi pada penelitian ini menggunakan kelas VII di MTsN 2 Bandar Lampung. Kelas VIII dipilih secara acak menggunakan tekhnik simple random. Tekhnik Pengumpulan Data dengan Angket, Wawancara, Dokumentasi. Pengumpulan data dilakukan dengan selembaran kelayakan yang berupa kuisioner yang berdasarkan skala likert. Lembar validasi terdiri dari Lembar Validasi Ahli dan Respon Siswa. Penyebaran kuisioner pada siswa ini bertujuan untuk 
mengetahui akan ketertarikan siswa untuk lebih bersemangat belajar dengan menggunakan modul yang telah dikembangkan. Teknik Analisis Data yang digunakan untuk melihat peningkatan kemampuan siswa dapat pula dilihat peningkatan minat belajarnya dengan Nilai $\mathrm{N}$-gain. Analisis Uji Efektivitas menggunakan Uji Effect Size.

\section{Hasil dan Pembahasan}

Hasil dari setiap tahapan prosedur pengembangan yang telah dilakukan adalah sebagai berikut: Define Tahap awali ni peneliti melakukan pra-penelitian di MTsN 2 Bandar Lampung guna untuk mengetahui akan kebutuhan siswa, Observasi dengan melakukan pengecekan kondisi pembelajaran dengan menyebarkan kuesioner kepada siswa.Dari hasil kuesioner yang telah dilakukan didapatkan permasalahan yang ada disekolah. Validasi ahli materi bertujuan untuk melihat kelayakan materi yang disajikan dalam modul baik dari segi materi,sistematika, kelengkapan, dan kesesuaian yang dikaitkan dengan saintifik dan berbagai hal yang berkaitan dengan materi. Penilaian oleh tiga validator ini dilihat dari aspek kelayakan isi dan kelayakan penyajian. Berikut hasil validasi tahap pertama.

Tabel 1

Hasil Validasi Ahli Materi Tahap I

\begin{tabular}{|c|c|c|c|c|}
\hline \multirow[t]{2}{*}{ Aspek } & & \multicolumn{2}{|c|}{ Validator } & \multirow[b]{2}{*}{ V3 } \\
\hline & Analisis & V1 & V2 & \\
\hline \multirow{3}{*}{ Kelayakan Isi } & $\sum$ Skor & 16 & 40 & 38 \\
\hline & & 1,5 & 3,63 & 3,45 \\
\hline & & & 2,86 & \\
\hline \multirow{5}{*}{ Kelayakan Penyajian } & Kriteria & \multicolumn{2}{|c|}{ Cukup Valid } & \\
\hline & $\sum$ Skor & 16 & 37 & 32 \\
\hline & & 1,6 & 3,7 & 3,2 \\
\hline & & & 2,83 & \\
\hline & Kriteria & \multicolumn{2}{|c|}{ Cukup Valid } & \\
\hline
\end{tabular}

Hasil validasi tahap pertama di atas menunjukan bahwa pada kelayakan isi mendapatkan hasil 2,86 dan kelayakan penyajian 2,83. Hasil validasi di atas menyatakan bahwa produk cukup baik namun masih perlu diperbaiki. Berikut hasil perbaikan produk awal

Setelah memperbaiki produk, peneliti melakukan pengecekkan kembali pada validator kembali. Berikut hasil data validasi tahap kedua:

Tabel 2

Hasil Validasi Ahli Materi Tahap II

\begin{tabular}{ccccc}
\hline \multirow{2}{*}{ Aspek } & \multirow{2}{*}{ Analisis } & V1 & V2 & V3 \\
\hline & SSkor & 40 & 40 & 38 \\
\hline
\end{tabular}




\begin{tabular}{|c|c|c|c|c|}
\hline \multirow[t]{3}{*}{ KelayakanIsi } & & 3,63 & 3,63 & 3,45 \\
\hline & & \multirow{2}{*}{\multicolumn{2}{|c|}{ Valid }} & \\
\hline & Kriteria & & & \multirow{4}{*}{$\begin{array}{l}32 \\
3,2\end{array}$} \\
\hline \multirow{4}{*}{ Kelayakan Penyajian } & $\sum$ Skor & \multirow{3}{*}{$\begin{array}{c}37 \\
3,7\end{array}$} & 37 & \\
\hline & & & 3,7 & \\
\hline & & & 3,53 & \\
\hline & Kriteria & \multicolumn{2}{|c|}{ Valid } & \\
\hline
\end{tabular}

Berdasarkan hasil validasi tahap kedua yang disajikan pada tabel 2 pada aspek kelayakan isi didapatkan hasil 3,57 dan aspek kelayakan penyajian 3,53. Berikut gambar diagram penilaian validasi ahli materi yang terdapat perubahan di setiap aspeknya.

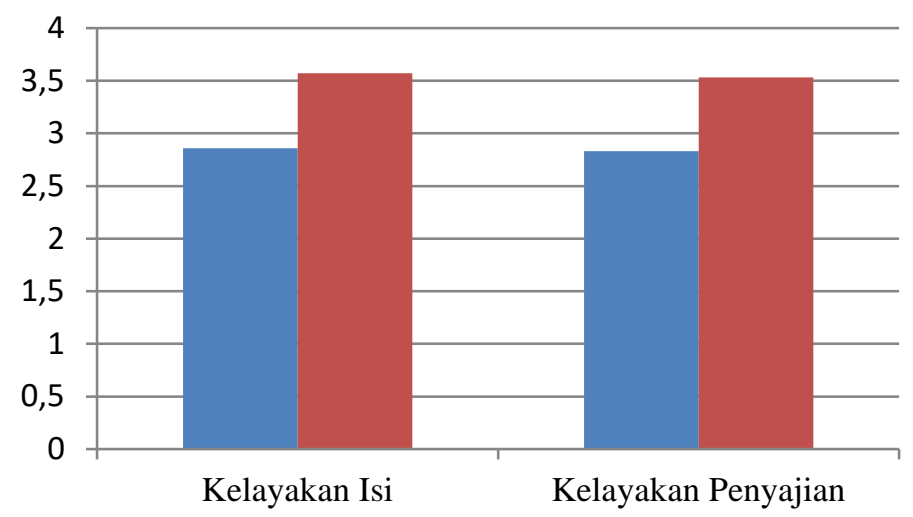

- Sebelum Revisi

- Setelah Revisi

Gambar 1. Diagram perbandingan penilaian ahli materi

Gambar diatas ialah hasil dari perbandingan penilaian ahli materi sebelum dan setelah dilakukan revisi, dari penjelasan di atas didapat bahwa setelah direvisi penilaian mengalami peningkatan pada setiap aspek. Setelah direvisi pada setiap aspek mengalami kenaikan yakni 0,71 pada kelayakan isi dan 0.7 pada kelayakan penyajian setelah dilakukan revisi dengan ini produk tidak perlu lagi diperbaiki dan dapat langsung digunakan. Berdasarkan hasil tahap awal diperoleh hasil 3,33, spek desain sampul modul 3,32 dan aspek desain isi modul 3,31. Hasil validasi menunjukan bahwa produk masih perlu diperbaiki. Berikut adalah saran dan perbaikan.

Tabel 3. Saran dan perbaikan ahli media

Tampilan sebelum dan sesudah diperbaiki

\begin{tabular}{llll}
\multicolumn{1}{c}{ Komentar } & Sindak Lanjut & Sebelum diperbaiki & Sesudah diperbaiki \\
\hline $\begin{array}{l}\text { Cover dibuat agar } \\
\text { lebih menarik dan } \\
\text { berwarna }\end{array}$ & $\begin{array}{l}\text { Membuat cover agar } \\
\text { lebih menarik dan } \\
\text { berwarna }\end{array}$ &
\end{tabular}




$\begin{array}{ll}\begin{array}{l}\text { Tambahkan } \\ \text { animasi, warna dan } \\ \text { kolom pengisian } \\ \text { tugas }\end{array} & \begin{array}{l}\text { Menambahkan animasi, } \\ \text { warna dan kolom } \\ \text { pengisian tugas }\end{array} \\ \begin{array}{l}\text { Tambahkan } \\ \text { macam-macam }\end{array} & \begin{array}{l}\text { Menambahkan macam- } \\ \text { macam kriteria soal }\end{array}\end{array}$
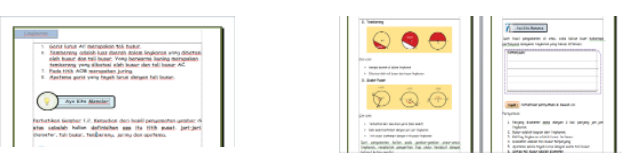

kriteria soal

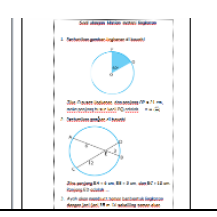

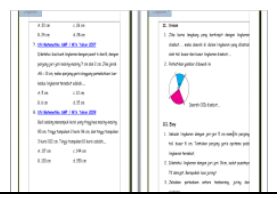

Pada ini dilakukan dengan menyebarkan angket respon peserta didik kelas VIII SMP. Tahap ini bertujuan untuk mengetahui efektivitas produk Peneliti melakukan tahap ini dengan membagikan angket kepada 24 peserta didik untuk uji kelompok besar, 8 siswa untuk uji kelompok kecil. Melihat peningkatan minat belajar pada siswa dilakukan dengan pembagian pretest sebelum membagikan modul dan postest setehah siswa belajar dengan menggunakan modul. Berikut perolehan pretest dan posttest siswa:

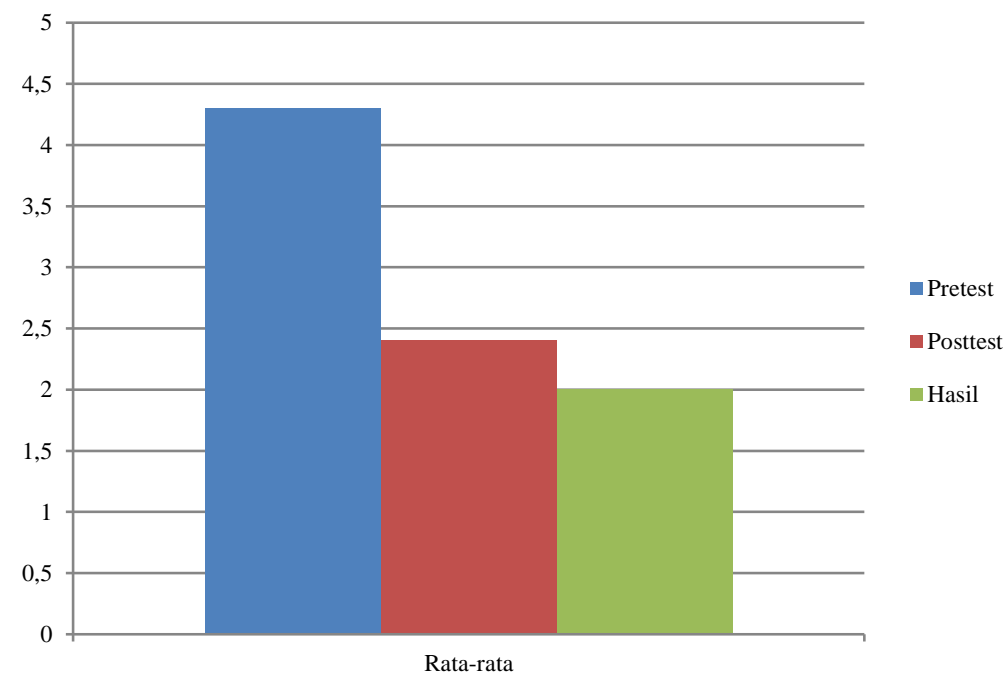

Gambar 2. Diagram perolehan pretest dan posttest siswa

Hasil perolehan nilai dari pembagian soal pretest dan postest didapatkan hasil nilai ratarata 64,39 dan posttest 90,15 dan dari hasil data keseluruhan 0,67 dengan kriteria "sedang". Penilaian produk dilakukan dengan membagikan angket dan meminta peserta didk mengisinya. Hasil penilaian masuk dalam kriteria sangat menarik pada kualitas produk. Berikut perolehan skor respon dan siswa: 


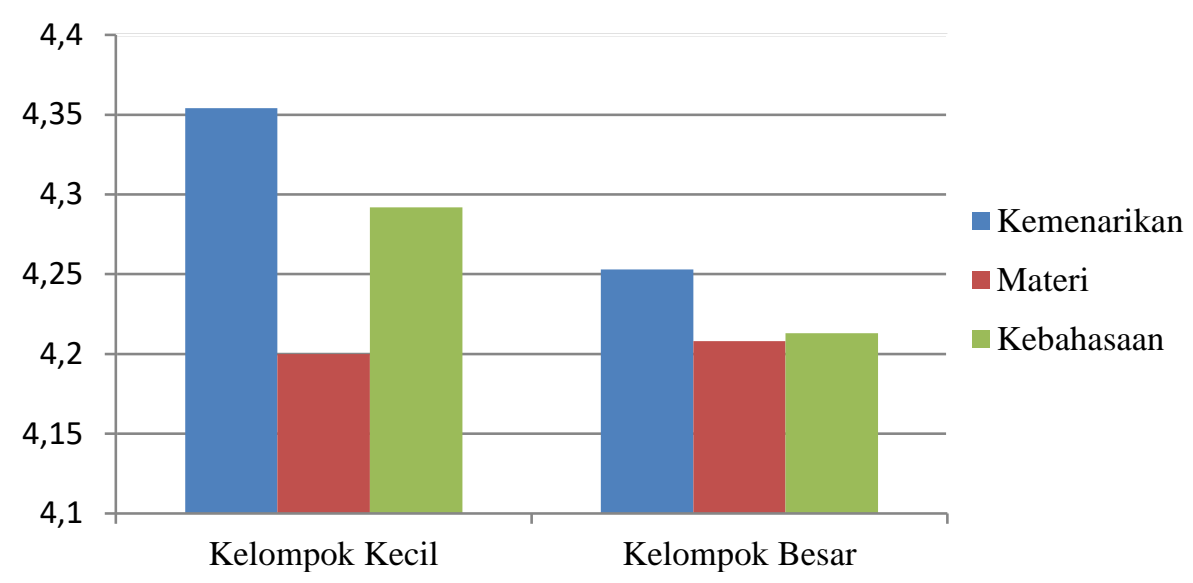

Gambar 3. Diagram perolehan respon siswa

Hasil uji respon siswa pada kelompok kecil diperoleh untuk kemenarikan dengan skor 4,35, kemanfaatan skor 4,20 dan kemudahan skor 4,29, dari semua aspek tersebut masuk ke dalam kategori sangat menarik. Rata-rata skor penilaian dari keseluruhan adalah 4,28. Hasil uji respon siswa kelompok kecil pada kemenarikan didapat skor 4,253, kemanfaatan 4,208 dan kemudahan 4,213,dari keseluruhan hasil pada uji kelompok besar juga masuk ke dalam kategori sangat menarik. Rata-rata skor penilaian dari keseluruhan adalah 4,229.

Penelitian ini dilakukan untuk mengembangkan modul pembelajaran berbasis saintifik pada materi lingkaran. Peneliti memilih menggunakan model pengembangan 4-D yaitu Define (pendefinisian), design (perencanaan), development (pengembangan) dan disseminate (penyebaran). Modul divalidasi oleh validator yang ahli sesuai dengan bidangnya, yaitu ahli materi dan ahli media. Tahap Define melakukan observas idengan menyebarkan angket kepadas siswa kelas VIII untuk mengetahui kebutuhan pembelajaran. Kemudian peneliti menganalisis dari data yang didapat bahwa siswa masih butuh media untuk lebih mudah belajar secara mandiri (Nugroho dkk., 2019; Sulistyaningrum dkk., 2015). Kemudian, peneliti mencoba untuk mengembangkan modul pembelajaran Berbasis Saintifik pada materi lingkaran. Design Tahap pengerjaan awal dengan mempersiapkan bahan dan merancang produk seperti materi, contoh soal,dan yang berkaitan dengan saintifik. Penjelasan materi serta seperti penjelasan serta mengajak siswa untuk dapat lebih aktif dan mandiri dalam proses pembelajaran. Sedangkan dalam mengaitkan materi dengan beberapa langkah dari saintifik yang dapat mengajarkan siswa untuk lebih aktif. Setelah semua sudah dipersiapkan peneliti memulai membuat modul yang berbasis saintifik Development

Tahap memvalidasi produk awal yang telah dirancang kepada validator hingga produk dinyatakan valid dan layak digunakan.. Berdasarkan hasil penilaian tahap pertama oleh 
validator ahli materi,kelayakan isi pada indikator kelengkapan isi menurut ahli materi belum mencakup semua materi sehingga perlu ditambahkan atau dilengkapi kembali sehingga diperoleh skor rata-rata dari semua sebanyak 2,84 dengan kriteria“cukup valid", kemudian peneliti memperbaiki produk sesuai dengan saran validator dan kembali melakukan validasi tahap kedua. Kemudian diperoleh hasil skor rata-rata dari semua aspek yaitu3,55 dengan kriteria "valid". Penilaian validasi ahli materi pada tahap pertama dan tahap kedua terdapat peningkatan sebesar 0,69. Sehingga dapat diartikan bahwa modul berbasis saintifik dinyatakan layak digunakan sebagai media pembelajaran serta sumber belajar mandiri siswa.

Setelah melakukan validasi dan produk telah dinyatakan valid. Berdasarkan hasil penilaian validasi pada tahap pertama, aspek keterlaksanaan pada indikator penyajian materi menurut ahli media masih belum menarik, validator memberi saran agar penjelasan materi untuk lebih memperbanyak gambar, warna dan animasi sehingga diperoleh skor rata-rata pada semua aspek sebanyak 3,32 dengan kriteria "valid", kemudian peneliti memperbaiki produk sesuai dengan saran validator dan kembali melakukan validasi tahap kedua. Sehingga diperoleh hasil skor rata-rata dari semua aspek yaitu 3,78 dengan kriteria“valid”. Penilaian validasi ahli media pada tahap pertama dan tahap kedua terdapat peningkatan sebesar 0,46. Sehingga dapat diartikan bahwa modul berbasis saintifik layak digunakan.

Setelah melakukan validasi peneliti melakukan ujicoba produk dilakukan dengan menyebar angket pada siswakelasVIII di MTs N 2 Bandar Lampung dengan 24 siswa untuk uji kelompok besar dan 8 siswa untuk uji kelompok kecil. Berdasarkan uji kelompok kecil diperoleh skor rata-rata yaitu 4,28 dan dinyatakan bahwa modul ini "sangat menarik". Hasil uji respon siswa pada kelompok besar diperoleh rata-rata skor penilaian dari keseluruhan aspek yaitu 4,22 dan dinyatakan bahwa modul ini“sangat menarik". Peneliti membagikan modul pada siswa dengan tujuan agar dapat melihat ketertarikan siswa terhadap produk yang telah mereka gunakan. Melihat peningkatan belajar pada siswa dilakukan dengan pembagian pretest sebelum membagikan modul dan postest setetah siwsa belajar dengan menggunakan modul dari data pretest didapatkan hasil nilai rata-rata 64,39 dan posttest 90,15 dan dari hasil data keseluruhan 0,67 dengan kriteria "sedang".

Tahap Disseminate adalah tahap penyebaran modul yang telah dikembangkan dan telah dinyatakan valid atau layak untuk digunakan. Tahap penyebaran ini dilakukan dengan menyebarkan produk dikelas VIII MTs 2 Bandar Lampung. Tahap ini bertujuan agar produk dapat dimanfaatkan dalam belajar mengajar di kelas. Hasil penelitian ini sama dengan percobaan sebelumnya, yaitu mengembangkan modul berbasis saintifik diperoleh respon yang 
positif dari siswa. Melalui penggunaan modul untuk meningkatnya minat belajar siswa, mengalami kenaikan dan tanggapan baik (Husni, 2018; Realita dkk., 2016; Widyaningrum dkk., 2013). Berdasarkan penelitian yang telah dilakukan sebelumnya, keterbaruan dari penelitian ini adalah modul yang dikembangkan berupa modul pembelajaran yang berbasis saintifik, dimana dengan saintifik ini mendukung siswa dapat dengan mudah untuk belajar secara mandiri.

Keefektifan modul pembelajaran matematika berbasis saintifik pada materi lingkaran diujikan dengan menggunakan perhitungan effect size. Perhitungan effect size dihitung dari hasil pretest dan posttest yang telah diberikan kepada siswa. Hasil yang telah dihitung menggunakan effect size dengan hasil " 0,95 " dengan kualifikasi "Tinggi” atau dapat dikatakan tingkat keefektifan "Tinggi”. Hasil keefektifan tinggi menunjukan modul yang dikembangkan berpengaruh untuk peningkatan hasil belajar siswa walaupun masih perlu ada yang diperbaiki dan dikembangkan lagi.

\section{Simpulan dan Saran}

Berdasarkan uraian dan perhitungan,maka dapat diambil kesimpulan bahwa, pada penelitian ini modul berbasis saintifik yang dikembangkan dengan beberapa tahap perbaikan baik dari validator ahli materi maupun media. Pada penerapan modul juga mendapat respon positif, ditunjukkan dari data hasil angket respon pendidik dengan skor rata-rata yang diperoleh 4,28 pada uji kelompok kecil dan pada uji kelompok besar 4,22 yang termasuk dalam kriteria "sangat menarik". Keefektifan modul pembelajaran matematika berbasis saintifik pada materi lingkaran diujikan dengan menggunakan perhitungan effect size. Perhitungan effect size dihitung dari hasil pretest dan posttest yang telah diberikan kepada siswa. Hasil yang telah dihitung menggunakan effect size dengan hasil "0,95" dengan kualifikasi "Tinggi" atau dapat dikatakan tingkat keefektifan "Tinggi”. Berdasarkan hasil penelitian pengembangan modul berbasis saintifik pada materi lingkaran, maka penulis mengemukakan saran sebagai berikut: Modul pembelajaran matematika berbasis saintifik yang dikembangkan perlu disempurnakan kembali, sehingga dapat menghasilakan produk yang lebih bermanfaat dan berkualitas. Diperlukankan pengembangan modul pembelajaran matematika berbasis saintifik pada materi lainnya yang dapat disesuaikan dengan kebutuhan siswa serta kondisi sekolah masing-masing agar kegiatan pembelajaran dapat berlangsung. Pengembangan modul pembelajaran matematika berbasis saintifik diperlukan adanya berbagai metode agar siswa lebih tertarik untuk belajar, diperlukannya lebih banyak contoh soal dan latihan untuk siwa belajar. 


\section{Referensi}

Abdullah, R. (2017). Pembelajaran dalam perspektif kreativitas guru dalam pemanfaatan media pembelajaran. Lantanida Journal, 4(1), 35-49.

Alifah, S., Narsih, D., \& Widiyarto, S. (2019). Pengaruh Metode Partisipatori Dan Minat Belajar Terhadap Kemampuan Berwirausaha Siswa Smk. Lectura: Jurnal Pendidikan, 10(1).

Husni, M. (2018). Pendidikan Islam Dalam Mambangun Etika Peradaban; Sebuah Kajian Diskurtif. Edureligia: Jurnal Pendidikan Agama Islam, 2(1), 28-40.

Ibda, H., \& Rahmadi, E. (2018). Penguatan literasi baru pada guru madrasah ibtidaiyah dalam menjawab tantangan era revolusi industri 4.0. JRTIE: Journal of Research and Thought of Islamic Education, 1(1), 1-21.I

Karlina, N. (2017). Pengembangan Bahan Ajar PAI Berbasis Pendekatan Saintifik Pada Materi Iman Kepada Mlaikat-Malaikat Kelas VIII Di SMP N 5 Bandar Lampung.

Khasanah, B. A., \& Fadila, A. (2018). Pengembangan Lkpd Geometri Transformasi Dengan Motif Tapis Lampung. JURNAL e-DuMath, 4(2), 59.

Kurniawan, A. (2016). Bentuk Perubahan Kesenian Tari Jathilan Desa Ketep Kecamatan Sawangan Kabupaten Magelang. ADITYA-Pendidikan Bahasa dan Sastra Jawa, 8(2), 31-32.

Lukman, L., \& Ishartiwi, I. (2014). Pengembangan Bahan Ajar Dengan Model Mind Map Untuk Pembelajaran Ilmu Pengetahuan Sosial Smp. Jurnal Inovasi Teknologi Pendidikan, 1(2), 109-122.

Maesaroh, S. (2013). Peranan metode pembelajaran terhadap minat dan prestasi belajar pendidikan agama Islam. Jurnal Kependidikan, 1(1), 150-168.

Mastur. (2017). Implementasi Kurikulum 2013 Dalam Pelaksanaan Pembelajaran Di SMP. Jurnal Inovasi Teknologi Pendidikan, 4(1), 50-64.

Mawardi, I. (2016). Nilai-Nilai Pendidikan Islam dalam Menjawab Tantangan Global (Sebuah Ide Reformulasi Kurikulum Pendidikan Islam). Jurnal Fakultas Agama Islam.

Ngafifi, M. (2014). Kemajuan teknologi dan pola hidup manusia dalam perspektif sosial budaya. Jurnal Pembangunan Pendidikan: Fondasi dan Aplikasi, 2(1).

Noor, A. (2019). Problematika pembelajaran pendidikan agama Islam di era digital. Prosiding Seminar Nasional Prodi PAI UMP.

Nugroho, A. M., Wardono, W., Waluyo, S. B., \& Cahyono, A. N. (2019). Kemampuan Berpikir Kreatif ditinjau dari Adversity Quotient pada Pembelajaran TPACK. PRISMA, Prosiding Seminar Nasional Matematika, 2, 40-45.

Pramesty, R. I. (2013). Pengembangan Alat Peraga KIT Fluida Statis Sebagai Media Pembelajaran Pada Sub Materi Fluida Statis Di Kelas XI IPA SMA Negeri 1 Mojosari, Mojokerto. Inovasi Pendidikan Fisika, 2(3).

Realita, A., Sukarmin, S., \& Sarwanto, S. (2016). Pengembangan Modul Fisika Berbasis Sains Teknologi Masyarakat (Stm) Pada Materi Fluida Statis Untuk Meningkatkan Motivasi Dan Hasil Belajar Siswa SMA Kelas X. INKUIRI: Jurnal Pendidikan IPA, 5(3), 113121. 
Sari, N. (2014). Re-Design Kurikulum Ekonomi Syariah Perguruan Tinggi Agama Islam. Jurnal Ilmiah Peuradeun, 2(3), 135-154.

Setiyadi, M. W. (2017). Pengembangan Modul Pembelajaran Biologi Berbasis Pendekatan Saintifik Untuk Meningkatkan Hasil Belajar Siswa. Journal of Educational Science and Technology (EST), 3(2), 102.

Siti Nurhasanah, \& A.Sobandi. (2016). Minat Belajar Sebagai Determinan Hasil Belajar Siswa. Jurnal Pendidikan Manajemen Perkantoran, 1(1), 135-142.

Somayasa, W., Natajaya, N., \& Candiasa, M. (2013). Pengembangan Modul Matematika Realistik disertai Asesmen Otentik untuk Meningkatkan Hasil Belajar Matematika Peserta Didik Kelas X di SMK Negeri 3 Singaraja. e-Journal Program Pascasarjana Universitas Pendidikan Ganesha Program Studi Pendidikan Dasar, 3, 1-12.

Suda, I. K. (2016). Pentingnya Media dalam Meningkatkan Kualitas Pembelajaran Siswa di Sekolah Dasar. Universitas Hindu Indonesia.

Suharni, S. (2015). Westernisasi Sebagai Problema Pendidikan Era Modern. Jurnal AlIjtimaiyyah, l(1).

Sulistyaningrum, D. E., Karyanto, P., \& Sunarno, W. (2015). Pengembangan modul berbasis model pembelajaran arias untuk memberdayakan motivasi dan berpikir kritis siswa pada materi ekosistem. Inkuiri: Jurnal Pendidikan IPA, 4(1), 104-116.

Supriadi, S. (2017). Konsep Pembaruan Sistem Pendidikan Islam Menurut Muhammad 'Abduh. Kordinat Jurnal Komunikasi Antar Perguruan Tinggi Agama Islam, 15(1), 31-60.

Wibowo, B. (2015). Analisis Tipologi Adaptasi Robert K. Merton Dalam Implementasi Pendekatan Saintifik Oleh Guru Di SMA Negeri 2 Sukoharjo. Sosialitas: Jurnal Ilmiah Pendidikan Sosiologi-Antropologi, 5(2), 164534.

Widyaningrum, R., Sarwanto, S., \& Karyanto, P. (2013). Pengembangan Modul Berorientasi Poe (Predict, Observe, Explain) Berwawasan Lingkungan Padamateri Pencemaran Untuk Meningkatkan Hasil Belajar Siswa. Bioedukasi: Jurnal Pendidikan Biologi, 6(1), 100-117.

Wiyanto. (2003). Pendekatan Saintifik pada perkuliahan dengan E-learning. 217-229. 